\author{
Kazimierz Sikora \\ Uniwersytet Jagielloński \\ Wydział Polonistyki \\ ORCID: 0000-0002-5686-1278; e-mail: k.sikora@uj.edu.pl
}

\title{
Gwarowa etykieta językowa i religia
}

\begin{abstract}
Abstrakt: W artykule podjęto próbę przedstawienia zależności pomiędzy licznie obecnymi w gwarze modlitewnymi formułami codziennej etykiety a tradycyjną chłopską religijnością i osadzonymi w niej: modelem wiejskiej grzeczności oraz systemem wartości i norm obyczajowych. Jak dowodzą analizy wybranych formuł grzecznościowych (quasi-religijnego powitania, pożegnania, powitania przy pracy i jedzeniu posiłków), mają one początek w kulturowym mechanizmie religijnej aksjologizacji rozmaitych sfer życia, skryptów, gestów kultury, oraz w sakralizacji pracy na roli i wszystkich obszarów związanej z nią aktywności człowieka. Należą one jednocześnie do kultury „dobrego słowa”, traktującej życzenie jako realny dar, zapewniający odbiorcy, z pomocą Boga, pomyślność, zdrowie i szczęście we wszelkich okolicznościach życia prywatnego i społecznego (nie wyłączając jedzenia i spożywania alkoholu). Artykuł reprezentuje antropologiczno-kulturowy nurt badań w dialektologii.
\end{abstract}

Słowa kluczowe: dialektologia, etykieta językowa, etnolingwistyka, religia.

\begin{abstract}
Rural dialect etiquette and religion. The article presents a relationship between prayer formulas of everyday etiquette used frequently in peasant dialects and traditional peasant religiosity, in which a model of rural politeness and a system of values and moral norms are embedded. An analysis of selected forms of address (quasi-religious welcomes, farewells and greetings at meal times and at work) shows that they originate from the cultural mechanism of the religious axiologisation of various spheres of life, scripts, gestures of culture, and from adding a sacral dimension to farming and all areas of human activity related to it. The analysed forms of address are part of the "kind word" culture that sees a wish as a tangible gift that, with the help of God, provides prosperity, good health and luck in all spheres of private and social life (including food and alcohol consumption). The paper follows the anthropological-cultural research trends in dialectology.
\end{abstract}

Keywords: dialectology, language etiquette, ethnolinguistics, religion.

W swoich badaniach nad wiejską etykietą językową natknąłem się na wyłożony w tytule artykułu problem, który zasadniczo nie doczekał się systematycznego opracowania na gruncie dialektologii. Idzie tu o funkcjonowanie w kulturze dobrego słowa (por. Sikora 2011; 2020) zwrotów i formuł typu modlitewnego i zarazem życzeniowego, odwołujących się wprost lub pośrednio do Boga (nadprzyrodzonej mocy), jako rzeczywistego sprawcy lub gwaranta ofiarowanego drugiemu werbalnie dobra (wymienię tu przykładowo prace: Krawczyk-Tyrpa 1997; Simonides 1998; Kowalski 2010a-b; Masłowska 2016; Sikora 2020). Trzeba też dodać, że wielu badaczy, poszukujących słusznie genezy takich quasi-religijnych formuł w czasach przedchrześcijańskich, 
traktuje je jako swoiste relikty synkretycznego, religijno-magicznego światopoglądu naszych przodków i kontynuacje dawnego, magicznego sposobu myślenia, uznającego naturalny charakter semiosis językowego znaku (jak np. znane i dziś: Tfu! Na psa urok!, Wypluj to słowo! i inne czynności zaprzeczające w jakiejś mierze wyobrażeniom o ugruntowanej racjonalności współczesnego człowieka, por. Chudzik 2002). Ślady tej sprawczo-życzeniowej intencji, polegającej na modlitewnej prośbie do Boga, są według Kazimierza Ożoga nadal obecne w wielu skonwencjonalizowanych grzecznościowych zwrotach polszczyzny ogólnej (por. Dzień dobry!; Ożóg 1990, 20-27) - mimo postępującej sekularyzacji kultury i laicyzacji obyczajów. Życzeniowej intencji, już całkowicie według nich zatartej (por. dawne *Bóg/Boże daj/zdarz Ci dobry dzień! / dobry wieczór; Cybulski 2003, 26-30), inni współcześni badacze odmawiają jednak obiegowym formułom codziennej etykiety (np. Kowalski 2009; 2010a, 113 i n.). Na wsi związek językowej grzeczności z religijnością i pobożnością pozostaje (przynajmniej w starszym pokoleniu) nadal w istotnej mierze żywy. Głównie dzięki eksponowanej roli w wiejskiej etykiecie interesującej nas grupy rozmaicie wyspecjalizowanych (w zakresie realizowanej funkcji pragmatycznej) modlitewnych formuł życzących. Należą do niej przykładowo (materiał własny, południowa Małopolska): Pómbóg dej dobre polnie 'południe'!, Panie Boże dopomóż!, Boże pomogej!, Szczęść Boże!, Bóg zapłoć!, Roc Boze/Poniezus pozegnać!, Boze prowodź!, Zostońcie z Bogiem!, Ostoj z Bogiym, Idź z Bogiym, Tak tyż Boże dej!, W imie Boze, kółko bruzdom!, Piyrse Bosko Proco, potym moja itp. - mające bez wątpienia quasi-religijną, modlitewną postać. Zdają się one wręcz dominować (weźmy tu powitania) nad zwrotami „świeckimi”, typu: witaj, jak się masz, co stychać - niezbyt częstymi w bardziej formalnych (nierównorzędnych pragmatycznie) kontaktach.

By uporządkować wywód, trzeba koniecznie dodać, że większość wymienionych tu przykładów znajduje potwierdzenie w badaniach obyczajów dawnych Polaków (por. zwł. Cybulski 2003) - w świecie kultury szlacheckiej doby średniopolskiej i feudalnej monarchii stanowej. Dość jednoznacznie wskazuje to na wspólny ich rodowód w polskiej kulturze. Konstatacja ta, jakkolwiek pozostaje hipotezą, skłania do pytania, jak i kiedy rozeszły się drogi wiejskiego i szlacheckiego (dalej i miejskiego - elitarnego i standardowego) modelu grzeczności, że interesujące nas religijne formuły dawnej etykiety przechowały się (lepiej lub gorzej) tylko w społecznościach doświadczających skutków społeczno-ekonomicznej degradacji i wykluczenia. Opierając się na ustaleniach Anity Pawłowskiej, kontynuującej badania Marka Cybulskiego nad dawną etykietą, możemy ostrożnie (!) przyjąć, że dokonało się to częściowo - już w okresie XVI i XVII, a ostatecznie - z końcem XVIII w. (por. Pawłowska 2016, 107-108; 2014, 218-222)1. Bardzo trudno tego dowieść, ponieważ nie mamy wiedzy nawet

\footnotetext{
${ }^{1}$ Podnieść tu należy, że dysponujemy rzeczową i wiarygodnie udokumentowaną wiedzą na temat dezintegracji etykiety typowej dla socjolektu szlacheckiego, która najsilniej wpłynęła na współczesne zwyczaje językowe obowiązujące w miejskim (standardowym) wzorcu kultury. M. Cybulski wskazuje na splot okoliczności historycznych (głównie skutków upadku Rzeczpospolitej, dezintegracji kultury szlacheckiej i społeczno-ekonomicznej degradacji rzesz ubogiej szlachty; por. np. Cybulski 1994). Oboje badaczy zwraca także uwagę na bardzo istotne czynniki kulturowo-światopoglądowe i polityczne: demokratyzację relacji społecznych, sekularyzację państwa, popularność idei racjonalizmu i empiryzmu, kulturotwórczą rolę przełomu pozytywistycznego w Polsce, urbanizacji, ukształtowania się nowego typu państwowości opartej na
} 
o tym, jak zwracali się do swoich oficerów kosynierzy Kościuszki, a cóż dopiero jakim naprawdę obyczajom językowym hołdowali między sobą polscy chłopi. Pogląd swój mogę jedynie odnieść do przesłanek pośrednich. Na pierwszym miejscu stawiałbym tu brak widomych znamion laicyzacji obyczajów (np. każdy dzień kończy i zaczyna modlitwa; każdą pracę - pobożne westchnienie do Boga, por. Krawczyk-Tyrpa 1997; Simonides 1998) i zachowanie na wsi większości dawnych formuł etykietalnych modlitewnej proweniencji, zwykle w niezeświecczonej postaci, np.: Bóg zapłać!, Pomaga Bóg!, Szczęść Boże!, Daj Panie Boże!, Boże wystysz!, Racz Boże pożegnać (to jadło)!, Boże prowadź!, Zostań z Bogiem! itp. itd. Na drugim - fakt tylko pozornie mało istotny, jakim jest stwierdzone w toku skrupulatnych badań źródłowych (por. Pawłowska 2014; częściowo też Cybulski 2003) systematyczne ograniczanie się społecznej ekstensji takich formuł do niższych warstw społecznych - chłopów i najuboższej szlachty (faktycznie w okresie od końca XVIII do końca lat 30. XIX w. szlacheckiej gołocie, szlachcie bezrolnej i czynszowej nie udało się uniknąć deklasacji). Bardzo dobrym przykładem mogłoby tu być podziękowanie Bóg zapłać, które na opisanej wyżej zasadzie już w pierwszym wieku doby nowopolskiej ustąpiło miejsca performatywnemu dziękuję (por. Pawłowska 2014; Cybulski 1996). Istnienia świadectw tego zjawiska można dowieść także we współczesnych badaniach języka i obyczajów u potomków mieszkańców wsi szlacheckich na Podlasiu (np. Golachowska 2006).

Konfrontacja ogólnego (miejskiego) i gwarowego modelu grzeczności ukazuje głębokie zakotwiczenie zwyczajów językowych wsi w tradycji i systemie wartości zgodnym $\mathrm{z}$ duchem tzw. tradycyjnego polskiego katolicyzmu. Ten wyjątkowy w polskiej kulturze (por. etos ciężkiej pracy na roli i pracowitości jako miara wartości człowieka) system aksjologiczny jest ugruntowany na przekonaniu o nadrzędności wartości wspólnotowych nad indywidualnymi (np. potrzebą miłości, osobistego szczęścia), co znajduje bezpośredni wyraz w najgłębiej utrwalonym w zbiorowej świadomości wsi przeświadczeniu o bezwzględnej konieczności stałego utrwalania społecznej więzi łączącej jej mieszkańców. W niektórych wypadkach (np. pielgrzymki, klęski żywiołowe, pożary, strajki chłopskie, budowa kościoła) więź ta wykracza poza relacje rodzinno-rodowe i wioskowe, obejmując wspólnotę parafii i pochodzenia (więź stanowa). W różnych sytuacjach zagrażających jej trwaniu, wieś zdolna jest do najwyższych poświęceń i wielkiej solidarności, jak np. ratowanie zbiorów czy... wybudowanie w ciągu jednej

\footnotetext{
gospodarce przemysłowej i kapitalistycznej itp. (por. Pawłowska 2016, 107-111). Mówimy tu o zjawiskach z punktu widzenia wsi zewnętrznych, które nie wpłynęły na kształt tradycyjnej kultury chłopskiej lub doświadczyła ich ona w niewielkim stopniu. Istotną cezurą w tym względzie pozostaje dopiero uwłaszczenie chłopów i otwarcie możliwości społeczno-ekonomicznego i politycznego awansu tej wykluczonej i najliczniejszej grupy społecznej, co dokonywało się powoli acz uporczywie - mimo nędzy, klęsk głodu, przymusu emigracji zarobkowej (por. Leszczyński 2020, 369-394). Nie będą mnie tu interesować ani zmiany w rozbudowanej tytulaturze, zarzucenie napuszonych formuł typu służby zalecam, sługa uniżony, czołem biję za cześć JWP starosty, zanikanie relacji pan : sługa, upowszechnienie się adresatywów Pan/Pani +3 osoba orzeczenia w 2 połowie XIX w. w miastach (w kontaktach równorzędnych i stereotypowych społecznie, nawet panie malarzu, panie mlynarzu), ani przyjęcie się bardziej demokratycznych, neutralnych - obojętnych społecznie i świeckich (por. Bóg/Boże daj dobry dzień/wieczór $\rightarrow$ dzień dobry, dobry wieczór; do widzenia, dziękuję, proszę, przepraszam) form etykiety. Sprawy te nabrały na wsi znaczenia, dopiero gdy wyszła ona z kulturowej izolacji i otwarła się ona wpływy zewnętrzne; w wielu regionach Polski nastąpiło to dopiero w latach 60. ub. wieku (por. np. Sikora 1993).
} 
nocy kościoła w Nowosiółkach w pow. leskim w sierpniu 1975 r. (takiej sztuki dokazali też niegdyś, w 1741 r. ewangelicy w Skarszewach, co utwierdza przekonanie o szczególnej pozycji wartości religijnych w życiu społecznym).

$\mathrm{Z}$ przedstawionych ustaleń wynika uznanie szczególnej roli tradycji w funkcjonowaniu wiejskiej wspólnoty. Ona jest źródłem użytecznej wiedzy w codziennych okolicznościach egzystencji, dostarcza sprawdzonych przez pokolenia rozwiązań, chroni przed nieodwracalnymi, katastrofalnymi błędami (np. głodem, będącym skutkiem nieprzestrzegania właściwych terminów prac rolnych; chorobami bydła itp.). Sięga się do niej zwłaszcza w sprawach istotnych, czerpie chętnie z tego źródła mądrości i autorytetu. Jej wyroki są ostateczne i nie podlegają apelacji - tym bardziej, że ostatnią i najważniejszą instancją w świecie chłopskich wartości pozostaje Bóg i religia, siła sprawcza życia i zmian przyrody, równie mocno osadzona w tej domenie kultury duchowej wsi. Przywiązanie do religii, przeświadczenie o trwałym porządku świata i stałości zasad moralnych i wartości jest mocno osadzone na tym fundamencie: Bóg jest nie tylko dawcą życia, ale i uczestnikiem spraw ludzkich (przebywa w otaczającym nas świecie), strzeże porządku świata i należącego doń człowieka (por. Kałwa 2008, 234-235). Te ogólne stwierdzenia wymagają rozwinięcia i egzemplifikacji, bowiem ich wystarczającą przesłanką nie może być sama eksponowana rola w etykiecie językowej formuł pochodzenia modlitewnego. Wypada jednak zaznaczyć, że na to zjawisko trzeba spojrzeć szerzej, przez pryzmat kulturowego mechanizmu religijnej aksjologizacji rozmaitych sfer życia, skryptów i gestów kultury i łączenia ich z autorytetem sacrum, bez którego nie może się obejść ani wiosenna orka, ani świętowanie, pozdrawianie się, ani nawet spożywanie pokarmów (darów Bożych) czy alkoholu, por. przepijanie do młodszego współbiesiadnika: Dej ci Boze zdrowie, Jasiek! - Pijcie z Bogem, ujku! (Świętek 1896, 280-281).

Przenikające wiejską aksjologię, etykę i obyczajowość przekonanie, że wszystko, co dobre, pochodzi od Boga (szerzej na ten temat w Sikora 2020, 75 i n.) znajduje wyraz nawet w tak nieoczywistej kwestii, jaką jest stosunek do ciężkiej pracy, „krwawicy" będącej zarówno dobrodziejstwem, jak i przekleństwem chłopskiego życia; jako pojęcie - podlegającej semantycznej ambiwalencji. Wspólnota ludzi ciężkiej pracy na roli, doświadczająca wielowiekowej społecznej i politycznej degradacji, pogardliwego traktowania, tworzy kulturę afirmującą rolniczy trud przez jego sakralizację (także plonów i chleba), w czym zamyka się podstawowy sens agrocentrycznego systemu kulturowego. To fascynujące zjawisko, dające także współczesne refleksy w wartościowaniu pracy fizycznej w polskiej kulturze, doczekało się wielostronnego i rzetelnego opracowania w literaturze naukowej, nie ma więc potrzeby przywoływania poczynionych tam ustaleń. Do najważniejszych moim zdaniem prac, poświęconych temu zagadnieniu na gruncie dialektologii i lingwistyki antropologiczno-kulturowej należą studia i artykuły: Małgorzaty Mazurkiewicz $(1989 ;$ 1990; 1993) oraz Haliny Pelcowej $(2015 ; 2018)$ i Jerzego Bartmińskiego (2018), który badając profile pojęciowe pracy i roboty, doszedł do przekonywającego wniosku, że zawiera się w nich głęboki kontrast społeczno-kulturowego doświadczenia różnych grup społecznych i zgoła odmiennych systemów wartości: elitarnego, szlachecko-inteligenckiego i ludowego, chłopsko-plebejskiego (Bartmiński 2018, 289). Jest to całkowicie zbieżne z wynikami moich badań. Tematem pracy ludzkiej zajmuje się ważna interdyscyplinarna publikacja książkowa (wymieniona w bibliografii) Praca ludzka $w$ perspektywie interdyscyplinarnej, będąca pokłosiem 
konferencji naukowej pod hasłem „Praca ludzka”, zorganizowanej w Lublinie z inicjatywy badaczy ośrodka lubelskiego i krakowskiej PAU w 2016 r. Z punktu widzenia językowej etykiety godny podkreślenia jest fakt, że kultura wiejska wydała bardzo charakterystyczną grupę powitań i pozdrowień przy pracy, wiążących pomyślność i urodzaj z Boską pomocą i opieką.

Józef Styk, lubelski socjolog (UMCS), znawca problemu ludowej aksjologii, podkreśla, jak ważne i wyjątkowe miejsce zajmuje religia w chłopskim systemie wartości, zwraca uwagę na dominację w tradycyjnej kulturze ludowej „religijnego typu waloryzacji światopoglądowej”, prócz struktur zbiorowej świadomości i mentalności chłopstwa, ściśle powiązanego z właściwym tej kulturze agrocentryzmem i lokalnością (Styk 1999, 92-100). Rozumieć to można tak (trywializując nieco), że człowiek, wygnany z raju przez swego Stwórcę i stworzyciela świata, został zobowiązany do opieki nad ziemią, matką żywicielką, przyrodą i wszystkimi żyjącymi stworzeniami. Święta ziemia (jak w znanym przekleństwie), sama nosząca cechy boskości, nie jest bezwarunkowym darem i przedmiotem użytkowania, a tym bardziej - bezmyślnej eksploatacji. Traktowana nieetycznie (niezgodnie z Bożym zamysłem) może odmówić człowiekowi plonów, a nawet nie przyjąć kogoś podłego po śmierci. I na odwrót - traktowana z szacunkiem, należycie i etycznie - ,jak Pan Bóg przykazał”, za Boskim błogosławieństwem odwzajemnia się człowiekowi obfitością plonów i dostatkiem. Tak więc pozostający zwornikiem chłopskiego, agrarnego światopoglądu związek człowieka z ziemią niewątpliwie także ma religijny charakter. To myślenie o świecie i sensie życia człowieka sakralizuje całą sferę rolniczego trudu i podporządkowanego jej niemal bez reszty życia na wsi. Święci się więc pola, zboże na siew, owies do sprawowania kolędniczych obrzędów, konia i gospodarza przed wyjazdem do pracy, furę gnoju wywożonego na pole, śpiewa godzinki przy porannym obrządku przy krowach (!), wzywa pomocy Boga i Jego świętych w opiece nad sadzoną kapustą, grochem czy ziemniakami; używa powszechnie święconych ziół, soli św. Agaty, święconej wody, świętych obrazów, kadzidła, kredy w celach leczniczych, apotropeicznych czy prokreacyjnych, wita i żegna modlitwą (często zbiorową, rodzinną) dzień, ogień na nalepie, modlitewnym westchnieniem rozpoczyna się każdą pracę, nawet zwykły posiłek (spożywa się wszak Dary Boże) przyjmuje taki sakralny charakter i w niczym nie przypomina gwarnego, wesołego i sytego ucztowania, przypisywanego polskiej kulturze stołu. Większości tych symboliczno-obrzędowych czynności regularnie towarzyszą słowne formuły, służące spełnieniu obrzędu, zwykle też są jego centralnym elementem.

Nie ma tu miejsca na rozwijanie tego wątku, nie można jednak zbyć milczeniem faktu, że podniesiony problem był przemilczany i marginalizowany (przede wszystkim ze względów ideologicznych) w nauce XIX i XX w., traktowany w opisach tzw. tradycyjnej kultury chłopskiej jako wstydliwe dziedzictwo zabobonu i braku ogłady. Szczególnie odstręczająco działały w tym względzie rozmaite, wskazane tu działania, których nie wiązano z religijnością lecz z wiejskim zabobonem²,

\footnotetext{
${ }^{2}$ Negatywnie, jako istotną barierę w społecznym i kulturalnym awansie wsi, traktowali ten tradycjonalny światopogląd wybitni działacze ruchu ludowego (np. Wincenty Witos i Maciej Rataj) - sami wywodzący się z chłopstwa. Taki sposób waloryzacji przeszłości i tradycji w znacznej mierze utrwalił się na wsi i sprawił, że sprawy te postrzegane są jako wstydliwe dziedzictwo, co w istocie deformuje i spłyca rozwijający
} 
skutecznie utrwalonym w kulturze elit (co najmniej od czasów przełomu pozytywistycznego) obrazem wsi ciemnej, zacofanej, wymagającej oświeceniowej i cywilizacyjnej misji. Stworzono więc zgoła nieprawdziwy zewnętrzny stereotyp mieszkańców wsi jakichś „swoich obcych”, polskich Irokezów (por. Bukraba-Rylska 2010; 2017), niezdolnych o sprostania wymogom współczesności, których za rękę trzeba wyprowadzić ze skansenu, w którym się jakoby sami zamknęli - głusi na rozmaite wpływy zewnętrzne i mądre zachęty do modernizacji. Nie do przyjęcia było dla naszych uczonych poprzedników to, że synkretyczny (religijno-magiczny) wiejski światopogląd zawierał zbyt wiele elementów magicznych, czynności i gestów służących agrarnej obrzędowości i sprowadzaniu urodzaju; także perlokucyjnych formuł werbalnych, wyrażających naiwną wiarę w sprawczą moc bliskiego Bogu obrzędowego słowa (por. przy siewie: Panie Boże zaródźże tyz $w$ dziesiyńcioro, Rzucam przodzi dla Ciebie, Boze, ptakom niebieskiem, robastwu podziemnemu i sobie. Boze zaródź!; np. Dworakowski 1964, 128).

$\mathrm{Na}$ tle zarysowanego socjokulturowego pejzażu nie dziwi więc obecność tak licznych religijnych formuł etykiety w kulturze wsi. Ich używanie (prócz oczywistych funkcji pragmatycznych powitania, pożegnania, podziękowania itp.) jest z interesującego nas punktu widzenia tożsame z praktykowaniem pobożności i religijności; nieużywanie, stronienie od nich - było do niedawna grzechem, obrazą Boską. W umoralniających gawędach, biorących za temat przestrzeganie norm obyczajowych, znajdujemy świadectwa tych przekonań. Oto np. pokutująca dusza wyznaje przed swym wybawcą, że doświadcza kary (straszy w lesie po nocy głośnym kichaniem) za to, że jako żyjący człowiek nigdy nikomu nie powiedział za życia: Dej (Wom/ci) Boze zdrowie! (czyli „Na zdrowie!”) w grzecznej reakcji na kichnięcie (zapisane niedawno przez uczestników obozu dialektologicznego Koła Naukowego Językoznawców Studentów UJ im. M. Karasia w Pcimiu koło Myślenic; por. Karpeta, Radziszewska 2021); za zignorowanie powitania/pozdrowienia przy pracy Daj Boże szczęście! rozgniewany Chrystus zmienił aroganckich kosiarzy w bociany, które brodzą po łąkach (Pawłowicz 1896, 238). Jest kara, jest i nagroda w niebie za życzliwość i empatię: zapadła mi w pamięć scena, kiedy dziewczynka wracająca ze szkoły pomogła zbierać starszej kobiecie rozsypane po drodze zakupy i doczekała się za to podziękowania: Dziecko, ty mosz już na siódmyj kupce $w$ niebie naskłodane! W większości podobnych zdarzeń słyszało się na wsi proste Bóg zapłać!, które w opinii moich starszych informatorów ma „swoją wagę" i głębszy sens, aniżeli nowomodne, konwencjonalne Dziękuję! W tym systemie waloryzacji rzeczywistości to sam Bóg, który „Dziwnie wysoko siedząc przecię z góry/ I co na niebie, i co jest na ziemi/ Oczyma widzi nieuchronionemi"’3 wciąż stoi na straży dobrych obyczajów na wsi i etycznego porządku świata.

się dyskurs regionalnej i lokalnej tożsamości. Tymczasem różnorakie przejawy myślenia magicznego są wciąż obecne w XXI w. (np. spluwanie przez lewe ramię, żegnanie się ze strachu, chronienie czerwonym kolorem niemowląt przez urokiem, chuchanie na znalezioną monetę, używanie do bardzo zaskakujących czynności święconej wody z Lourdes, wizyty u znachorów, szeptunek i wróżek, pielgrzymki do świętych źródełek itp. itd.; por. Chudzik 2002), a przedstawiane bywają z przymrużeniem oka, np. jako nieszkodliwy folklor czasu wolnego. Trudno to określić inaczej, aniżeli mistyfikacją tej szczególnej, wciąż żywej pamiątki przeszłości, która inne środowiska ma kompromitować.

${ }^{3}$ Psalm 113 (fragment) w tłumaczeniu Jana Kochanowskiego; tegoż: Dzieła Polskie, za edycją J. Krzyżanowskiego (Warszawa 1980). 
Tak jednoznaczne deklaracje światopoglądowe obce są scjentystycznemu paradygmatowi nauki, wykluczającemu wszelką ,irracjonalność” (nieweryfikowalność empiryczną) poznania, systematycznie ugruntowującemu swoją pozycję w XIX w. Z tego też względu dawni badacze woleli doszukiwać się za tą „fasadą” zewnętrznej religijności wsi ukrytych przejawów pierwotnych, przedchrześcijańskich słowiańskich wierzeń i obrzędów, a nie dociekać źródeł nieporozumienia w odmiennym, ludowym, rozumieniu religijności, w praktyce życia duchowego utożsamionej zazwyczaj z pobożnością ${ }^{4}$ (por. np. Pawłowicz 1896, 235 i n.). By takie gesty właściwie ocenić, trzeba wejść w krąg motywacji, sposobu rozumienia miejsca i roli człowieka w świecie. Zabieg taki pozwala zdjąć z nich stygmat anachronizmu i śmieszności (jak z pieszego pielgrzymowania Drogą św. Jakuba do Santiago de Compostela i składania krzyży wotywnych na Świętej Górze Grabarce). Babka „klepiąca” bezmyślnie pacierze, podhalański „święty” Pieterpaweł, kompromitujący poziom katechizmowej wiedzy religijnej u naszych dziadów, o cebrze czystości (zam. o cedrze...) śpiewane w Godzinkach itp. - nie są w tej mierze istotną przeszkodą, a raczej zakłócającym ogólny obraz refleksem, przysłaniającym liczne przykłady żywej (wiarygodnej) obecności Boga w wiejskim systemie wartości i norm obyczajowych.

Wiele rzeczowych i przenikliwych uwag i rozważań na temat tzw. „ludowej” religijności i „ludowego” polskiego katolicyzmu można znaleźć w pracach współczesnych socjologów. W szczególności dotyczy to bardzo obiektywnych w tym względzie studiów Ludwika Stommy (2002, 247-250) i Izabelli Bukraby-Rylskiej (Bukraba-Rylska 2008, 510-515), konfrontujących wiejską kulturę religijną i pobożność zarówno z oficjalnym, (przed- i posoborowym) nauczaniem Kościoła katolickiego, jak i światopoglądem innych środowisk i grup społecznych. Pominę tu ogólnie znane elementy charakterystyki negatywnej (np. słabe osadzenie w duchowości chrześcijańskiej, powierzchowność, bezrefleksyjność i silna rytualizacja praktyk zbiorowych, naiwny socjomorfizm, nacjonalizm wyznaniowy itp.). Z interesującego mnie najbardziej punktu widzenia o wiele ważniejsze wydają się takie cechy, jak wrażliwość na obecność sacrum w otaczającym świecie i życiu indywidualnym, sakralizacja wiejskiego świata i jego wartości, funkcjonowanie normy współodpowiedzialności za funkcjonowanie i przestrzeganie religijnych zakazów i norm, sensualizm i uczuciowość, naiwne przeżywanie głębi kontaktu ze Słowem. Fascynująca romantyków szczerość tego przeżycia w znacznej mierze kompensuje niedostatki intelektualnej refleksji. Warto w związku z powyższym jednak zastrzec, że analiza oracji weselnych ukazała obraz dość niejednoznaczny pod tym względem, ujawniający zaskakująco rozległy krąg inspiracji, obejmujący nie tylko wątki biblijne, ale i nauczanie kościoła. Wbrew więc temu, co się sądzi, ludowy retor, choć niepiśmienny, czynił przemyślany użytek z dobrze przyswojonych wspólnotowo przekazów religijnych, ilustrujących godne i prowadzące ku zbawieniu życie. I nie chodzi tu jedynie o modlitwy ustalone, codzienne

${ }^{4}$ Swoją bardzo krytyczną diagnozę tradycyjnej religijności wsi małopolskiej pozostawił w swych pismach Seweryn Udziela: „wieśniak tutejszy jest bardzo religijny, bardzo pobożny. Pobożność ta jednak to pobożność przeważnie zewnętrzna, z głębi duszy nie wypływająca. Mało jest takich, którzy starają się żyć według zasad wiary. Masa ludowa nie rozumie ani odmawianej modlitwy, ani wyznawanych zasad wiary" (Udziela 1889, 592). 
i wotywne, litanie i pieśni; równie często pojawiają się przetworzenia przypowieści, fragmenty czytań liturgicznych, opisu stworzenia świata, zwiastowania NM Panny, cudu w Kanie Galilejskiej, żywoty niektórych świętych, nie mówiąc o przekazach apokryficznych. Szczególnie wyraziste w oracjach są rozmaite religijno-etyczne odniesienia do Świętej Rodziny - jako wzoru cnotliwego życia i spełniania społecznych obowiązków przyjmowanych w sakramencie małżeństwa. Trywializując nieco, należałoby stwierdzić, że chłop polski w dostępny i sobie właściwy sposób starał się zbliżyć do Boga, nawet jeśli przybierało to postać płytkiej pobożności i praktykowanej dość bezrefleksyjnie, rodzinnie i zbiorowo obrzędowości. Rozwijanie tego wątku należałoby pozostawić przykładom (np. wiarygodnym relacjom na temat obrzędowości rodzinnej, przestrzegania postów, pielgrzymek do miejsc świętych), w wystarczającym stopniu zadanie to spełnić może także przegląd wybranych formuł etykiety. Z powodzeniem ten cel zrealizują wiejskie powitania, pożegnania i pozdrowienia przy pracy i posiłku.

Najgłębszy, jak się wydaje, pokład etykietalnych formuł religijnych, używanych w sferze codziennej komunikacji, stanowią powitania oparte na zdaniowej formule modlitewnej prośby-życzenia, którym nadawca apeluje do Boga o udzielenie dobra odbiorcy (beneficjentowi życzenia) - stosownie do pory dnia i czasu spotkania. Wyjściowa formuła (wspólna gwarom, językowi ogólnemu i językom słowiańskim: *Bóg/Boże daj/zdarz Ci dobry dzień! / dobre rano (jutro) / dobre śródpołudnie / dobre dopołudnie / dobre południe / dobre odpołudnie / dobry odwieczerz / dobry wieczór / dobrą noc; Cybulski 2003, 26-30; Sikora 2020, 82, 121-125; Krawczyk-Tyrpa 1997) uległa znacznej konwencjonalizacji w gwarach i redukcji o podłożu frekwencyjnym. Prawdopodobnie przebiegała ona według następującego schematu: Daj Pan Bóg/Boże (wam/ ci) dobre południe! $\rightarrow$ Dobre poludnie (wam/ci)! itp. O ile pomijanie osoby beneficjenta jest uzasadnione pragmatycznie, o tyle niewymieniane osoby czynnika sprawczego (Boga) świadczyć mogłaby o postępującym procesie sekularyzacji pierwotnie religijnych formuł (i samej kultury ludowej - w ogólności). Zatarcie się modlitewnego charakteru formuły jest jednak hipotezą, którą nietrudno podważyć. W świadomości użytkowników gwary ów pierwowzór funkcjonuje bowiem jako wariant staranny (jak Niech będzie pochwalony Jezus Chrystus! w stosunku do: Pochwalony!), por. Starzik byli radzi, jak im tė̇ jeszcze kiery wczas rano powiedziol po downymu: Dej Boże dobry dziyń! (Wronicz 1995, 55). Obecność takich wariantów potwierdza jednocześnie istnienie świadomości ich religijnej motywacji ${ }^{5}$. Za religijny sens życzenia, wyrażanego przez takie etykietalne formuły, można by uznać za Anną Tyrpą (Krawczyk-Tyrpa 1997, 248-249), krótką modlitwę wstawienniczą, zawierająca prośbę nadawcy o boską opiekę i błogosławieństwo dla spotkanego człowieka. Należą one niewątpliwie do ogólnosłowiańskiego dziedzictwa kulturowego ${ }^{6}$ i być może mają jeszcze przedchrześcijańskie korzenie.

\footnotetext{
${ }^{5} \mathrm{Na}$ podstawie własnych badań można uznać, że takie powitania jeszcze 60-70 lat temu należały do repertuaru obiegowych zwrotów, używanych powszechnie - stąd obecność w polszczyźnie integrujących zbiorowe doświadczenie kulturowe zwrotów dzień dobry i dobry wieczór. Wiejskie pochodzenia zdradza konsekwentna prepozycja przymiotnika dobry (dobry dzień, dobry wieczór) oraz biernikowa postać frazy nominalnej, por. dobrom noc miyjcie! (por. też Cybulski 2003, 26 i n.).

${ }^{6}$ Podobne formuły nie są obce innym językom słowiańskim, por.: Dobré ráno!, Dobrý deň!, Dobrý večer! (j. słowacki); Доброе утро!, Добрый день!, Добрый вечер! (j. rosyjski); Добро јутро!, Добар дан!,
} 
Osobne i wyróżnione miejsce w wiejskiej etykiecie zajmuje powitanie: Niech będzie pochwalony Jezus Chrystus! - Na wieki wieków. Amen! Niewątpliwie upowszechniło się ono dzięki autorytetowi Kościoła katolickiego, stosunkowo późno (z końcem XVII w.), jako polskie tłumaczenie zatwierdzonej do powszechnego użytku przez papieża Sykstusa V (w 1589 r.) formuły łacińskiej (pierwotnie stosowanej między zakonnikami i duchowieństwem): Laudetur Iesus Christus! - In saecula saeculorum. Amen (por. Cross, Livingstone 2004, 1044). Na podstawie listu papieża Benedykta XIII (1724-1730) Pawłowska $(2016,108)$ przypuszcza, że mogło się to na naszych ziemiach dokonać na przełomie XVII/XVIII w. Od początku jednak ten sposób witania się nosił znamiona plebejskości (praktykowało go głównie chłopstwo i uboga szlachta; por. też Cybulski 2003, 30-31). Poczucie religijnej wartości tego chrześcijańskiego powitania musiało być żywe, skoro pielęgnowano ten zwyczaj nawet w niektórych majątkach ziemiańskich, należących do bardziej religijnych przedstawicieli polskiej arystokracji. Jednak pośród polskiej szlachty ten sposób witania się boskim słowem nie cieszył się uznaniem, ostatecznie przylgnęło do niego skojarzenie z chłopskimi zwyczajami i wsią ${ }^{7}$. Powitanie Niech będzie pochwalony..., przyjmujące także bardziej poufałe warianty (zanotowano nawet samo Krystus! i Pokwolony! - Na wieki amyn!, Niekze bedzie na wieki!, Na wieki!, a nawet Niekze ta!) wrósł bardzo głęboko w kulturę wsi; nie sposób sobie wręcz bez niego wyobrazić sfery kontaktów stereotypowych i nierównorzędnych pragmatycznie. Warianty skrócone noszą znamiona poufałości; można ich używać tylko w sytuacjach dopuszczających skrócenie dystansu między rozmówcami. Dopiero ostatnie dziesięciolecia, naznaczone inwazyjną obecnością formuł ogólnopolskich, doprowadziły do poważnego ograniczenia jego społecznej i komunikacyjnej ekstensji (wyjście do kościoła, wejście do cudzego domu, spotkanie osoby duchownej) (por. Kąś, Sikora 1994).

Niewątpliwie religijny charakter ma także stereotypowe wiejskie żegnanie się z gospodarzami na odchodnym. Wychodzący gość poleca Bogu i Jego opiece sprawy gospodarzy; oni zaś zanoszą do Boga życzenie przeznaczone dla gościa. Zachowania te tworzą specyficzny rytuał komunikacyjny, wymagający staranności, bowiem kończenie kontaktu zawsze jest okolicznością dla nadawcy trudną psychologicznie i „niebezpieczną” pragmatycznie (zwłaszcza gdy rozmówców dzieli znaczny dystans ról społecznych, a inicjatywa zamknięcia konwersacji należy do osoby o wyższej

\footnotetext{
Добро вечеr! (j. serbski); Dobro jutro!, Dober dan!, Dober večer! (j. słoweński). W języku polskim zaginęło powitanie poranne, zastąpione przez poszerzające zakres użycia Dzień dobry! Ten sam proces dokonuje się współcześnie w języku słowackim. Tożsamy strukturalnie i semantycznie model życzenia dobrego dnia realizuje wiele innych języków europejskich (por. niem. Guten Tag!, fr. Bonjour!, wł. Buongiorno!, ang. Good Morning!). Być może są one uniwersalnym znakiem empatii i radości ze spotkania, należącym do całej ludzkości (tę samą przejrzystą strukturę mają np. obiegowe powitania arabskie, hebrajskie i węgierskie).

7 Powitanie to było używane jeszcze na przełomie XIX i XX w. pomiędzy mieszkańcami ubogich wsi szlacheckich na Podlasiu, jednak zawsze (by podkreślić stanowe różnice) starano się dopełnić je prestiżowym Dzień dobry! czy Dobry wieczór! Nie stroniono od niego także w wypadku przygodnych spotkań, jednak zamiast Na wieki wieków... odpowiadano: Panie Boze dopomóż! Powitania te wyszły z użycia w ciągu XX w. (u potomków szlachty zastąpiły je powitania ogólnopolskie), i od tego czasu (jak wynika z badań Ewy Golachowskiej) religijne formuły powitalne jednoznacznie skojarzono ze zwyczajami chłopskimi (Golachowska 2006, 87-88).
} 
randze pragmatycznej ${ }^{8}$ ), ponieważ normy grzeczność wymagają, by nie uchybić i nie sprawić przykrości drugiej stronie, oczekującej okazania jej szacunku, życzliwości, serdeczności, zadowolenia ze spotkania, deklaracji jego powtórzenia, wdzięczności za gościnę itp. De facto w praktyce badawczej zwykle mamy do czynienia z końcową sekwencją skryptu pożegnania, obejmującą wymianę pozdrowień i spełnienie rytuału zakończenia rozmowy. Obejmować ona może prócz etykietalnych formuł także pozasłowne gesty pożegnalne: uśmiechy, podawanie sobie rąk, uściski, pocałunki, wręczanie zwyczajowego upominku - gościńca itp. (por. Nęcki 2000, 151-152; Marcjanik 2014, 341 i n.). Niedopełnienie tych towarzyskich obowiązków jest oceniane zdecydowanie źle i przynosi nadawcy kompromitację. Brak oczekiwanej reakcji drugiej strony jest także poważnym naruszeniem norm grzeczności, dość jednoznacznie implikuje niechęć i wrogość w stosunku do nadawcy. Przeciągające się oczekiwanie na pożegnanie lub jego brak jest - dodajmy - w polskiej kulturze obraźliwe (por. Marcjanik 1997, 269).

Rzecz godna podkreślenia, quasi-modlitewne formuły pożegnalne tworzą w gwarze najbardziej staranną, formalną ich warstwę. Szukając właściwego określenia ich językowo-kulturowej i społecznej ekstensji, należałoby je uznać za wykładniki pragmatycznej funkcji pożegnania w każdej bardziej oficjalnej sytuacji i wypadku nierównorzędnej (niesymetrycznej) relacji między rozmówcami. Kulturowy skrypt pożegnania pozostawia zasadniczo inicjatywę osobie kończącej kontakt (wychodzącej z cudzego domu). Kolejność replik może się zmienić, jeśli rozmówców łączy zażyłość albo do głosu dochodzi prymarnie życzeniowa intencja formuły (np. pragnienie okazania ciepłych uczuć osobie opuszczającej rodzinny, gościnny dom na dłużej). Dialogiczna formuła wiejskiego pożegnania przybiera zazwyczaj ogólnie znaną, skonwencjonalizowaną postać (Krakowskie):

\section{- Z Panym Bogiym (Jezusym) ostońcie/ostoń [zostońcie itp.] / Zostońcie/zostoń [ostońcie itp.] z Bogiem! \\ - Z Panym Bogiym (idźcie, jedźcie / idź, jedź)!}

Za dar dobrego, boskiego słowa należy gospodarzowi (gospodyni) pobożnie podziękować (czasem także dla zaznaczenia serdecznej więzi między wychodzącym a rozmówcą), por.: Bóg zapłoć! Takie podziękowanie można traktować jako ekspresywną obudowę aktu pożegnania i swoistą multiplikację wyrażonej już wcześniej intencji. W takiej sytuacji właściwą i przewidywalną reakcją gospodarza (gospodyni) jest ponowienie życzenia: Boze (wos, cie) prowodź! Może ono być samodzielną repliką-rekcją osoby żegnanej podstawową formułą pożegnania. Rozstawanie się z kimś bliskim, miłym sprzyja powstawaniu rozmaitych wariantów ekspresywnych omówionych formuł. Zasada: im obfitsze w słowach, tym serdeczniejsze i bardziej

\footnotetext{
8 Słowny folklor wsi zachował żartobliwą dykteryjkę o gościach „,z kamienia”, którym o konieczności zakończenia wizyty przypomniały dopiero słowa padające w rozmowie gospodarza i gospodyni: Babo, wiys ty co, podźmy spać, bo goście kcom juz iś do dómu! Dzieciom nieznającym jeszcze tej normy grzeczności, o konieczności pożegnania się w porę przypomnieć miało pouczenie ojca, matki, by nie zapomniały poprosić u wujka, ciotki itp. o „nowrót” (reprymendę, że pora już iść do domu). Owym ,nawrotem” mogło być pogrożenie miotłą lub paskiem.
} 
szczodre życzenia (por. Sikora 2015) znajduje potwierdzenie i w tym wypadku. Formułę rozbudowują inne akty grzecznościowe, zazwyczaj także zachowujące charakter modlitewnego westchnienia i wzmacniają życzeniową funkcję podstawy (przykład z Orawy):

- Z Bogiym, scynś wos ta Boze!

- Z Panym Bogiym, dej Panie Boze i wom / Scynś cie ta Boze, dej Pane Boze i tobie! A nie zaboc ta pozdrowić ojców! itp.

Tak nasycony dobrym słowem akt pożegnania może być zainicjowany przez gospodarza, gdy na zakończenie wizyty wskazują inne, pozajęzykowe sygnały. Kluczem do właściwego zrozumienia illokucyjnej mocy tego aktu jest religijny sens wyrażanej życzeniowej intencji. To ona sprawia, że np. użycie formuły: Krziz ci na droge! lub Niek wos Pon Jezus prowadzi! nie równa się pragmatycznemu samobójstwu (por. Żegnam Pana! Do widzenia! $)^{9}$.

Cytowane wyżej formy ekspresywnego pożegnania kierują naszą uwagę w stronę znacznie przejrzyściej osadzonych w sferze sacrum powitań/pozdrowień przy pracy. Sakralizacja rolniczego trudu i jego owoców jest dobrze rozpoznanym i opisanym zjawiskiem chłopskiej kultury, co zwalnia z absorbującej czas i miejsce konieczności jego bliższego przedstawienia (por. np. Mazurkiewicz 1989, 1990; Mazurkiewicz -Brzozowska 1993; Bartmiński 2018; Pelcowa 2015; Rak 2015, 195-224; Styk 1993; 1999; Simonides 1998; Bukraba-Rylska 2008, 362-381). Praca zajmuje centralne miejsce w systemie aksjologicznym wsi, a etos pracy kształtuje językowo-kulturowy wizerunek jej mieszkańca (por. np. Kąś 1994; Piechnik 2009). Jako podstawowa wartość splotła się w nierozerwalną całość z religijnym rozumieniem sensu życia i celu codziennego znoju. Sakralny wymiar stosunku człowieka do dającej chleb ziemi należy do istoty agrocentrycznego sytemu kulturowego (por. Styk 1999, 132-133; Sikora 2020, 118-121). Nie dziwi więc, że troska o posiadany grunt jest traktowana jako święty obowiązek, „powierzony” chłopu-rolnikowi przez samego Boga. Pracowitość jest miarą wartości człowieka, a lenistwo - jego upadku moralnego i grzechu. Miarą wielkiego pęknięcia w systemie wartości współczesnej wsi może być wobec tego widok pól stojących odłogiem i traktowanie roli jako nadającego się na sprzedaż przedmiotu (por. też: Pelcowa 2018). Niech to wystarczy, by uzasadnić szczególną rolę powitania-życzenia przy pracy i jego uderzającą trwałość także w czasach współczesnych.

Formuła powitania/pozdrowienia przy pracy wykazuje dość znaczną wariantywność. Wariancja ta zasadniczo nie ma jednak charakteru socjolingwistycznego i pragmatycznego, wnika raczej z dziedziczenia i specjalizacji tradycyjnych formul, używanych

\footnotetext{
9 Warunkiem użycia w opisanej sytuacji bardziej „świeckich” formuł (np.: Do uwidziska!, Krzepcie sie!, Miywojcie sie! itp.; można też w podzięce za gościnę życzyć zdrowia, pomyślności ) jest prymarnie zażyłość relacji między rozmówcami oraz symetryczny układ ich rangi pragmatycznej (np. koleżeństwo, przyjaźń, relacje rówieśnicze). Jak się wydaje, opuszczanie cudzego domu jest wyróżnione w wiejskiej etykiecie także ze względu na sakralizację tej okoliczności w chłopskiej kulturze (tak jak witanie się i pozdrawianie się w polu). Stosowanie formuł ogólnopolskich jest znakiem fałszywie pojmowanej nowoczesności i odrzucania wiejskich tradycji w komunikacyjnych rytuałach codzienności.
} 
niegdyś szeroko (także poza ludem) jako powitania ${ }^{10}$ (szerzej na ten temat: Sikora 2020, 108-111; Cybulski 1996; 2003; Pawłowska 2014; 2016), por. dla przykładu:

Boże dopomagaj! - Pam Bóg dej! (Skalite, Czadeckie)

Boże pomóż/dopomóż! - Boże ustysz/wystysz! / Dej Panie Boże! (Śląsk Cieszyński)

Panie Boże dopomóż! - Panie Boże zaptać (Wysokie Mazowieckie),

B'oze pómogoj! - Dej (Panie) Bloze! / Bóg zapłac! / Zdraw! ${ }^{11}$ (Chyżne, Orawa)

B'oze (Wom) (tam) pómogoj! - Dej Panie Jezu! / Panie B'oze ustys! (Podhale) $)^{12}$

Panie Boże dopomóż do pracy! - Bóg zapłać za dobre słowo! (okol. Radzynia Podlaskiego)

Scynś (Wos) (ta) B'oze! - Dej B'oze! / Bóg ustys! (Chyżne, Orawa)

Scynś B'oze! - Dej (Panie) Bloze! / Panie Bloze zapłoć / Bóg zapłoć! (Krakowskie)

Scynś B'oze (Wom) (tam)! - Dej Panie Jezu! / Dej (Panie) B'oze! / Panie B'oze ustys! (Podhale)

Szczęść Boże na robotę! - Panie Boże dopomóż! // Daj Panie Boże (Roztocze, okolice Narola) Szczęść Boże na robote! - Dej Panie Boże! (Żelisławice gm. Secemin, Kielecczyzna)

Badania terenowe wykazały, że w danym mikroregionie używa się z reguły dwóch wariantów życzącego powitania przy pracy. Najbardziej popularne na wsi pozostaje Szczęść Boże! - Daj Panie Boże!, podlegające rozmaitym modyfikacjom w zakresie odwitania (także żatrobliwym, por.: Dobry (lepsy) tyn, co pómºze!). Świadomość jego życzącej funkcji jest powszechna (głównie wskutek przejrzystej struktury życzeniowej), o czym najlepiej poucza dziękczynna, modlitewna forma repliki odbiorcy. Warto podkreślić, że w tej szczególnej grupie powitań dochodzi do neutralizacji pragmatycznej rangi rozmówców, a pierwszy (niezależnie od wieku, płci, pozycji społecznej) odzywa się ten, kto nadchodzi i dostrzega pracującego w polu. Na ile udało mi się sprawdzić, grzecznościowa formuła chrześcijańskiego powitania/pozdrowienia przy pracy występuje na całym obszarze etnicznym występowania języka polskiego, nawet w gwarach polskich w Łatgalii na Łotwie (por. Ulanowska 1895, III, 88).

Szczególną pamiątką synkretycznego, religijno-magicznego światopoglądu naszych wiejskich przodków pozostają życzenia zdrowia i dobrego apetytu jedzącym. Ten typ formuł grzecznościowych reprezentuje kulturę chłopskiego stołu. Zastając kogoś w trakcie spożywania posiłku (lub samemu dając znak do rozpoczęcia posiłku), należy zwrócić się do innych konwencjonalną formułą życzenia-błogosławieństwa, którego sens polega na prośbie do Boga o pobłogosławienie posiłku, opiekę nad jedzącymi i ich zdrowiem (̇̇egnać - pożegnaćlprzė̇egnać = 'pobłogosławić, obdarzyć szczęściem,

\footnotetext{
${ }_{10} \mathrm{Na}$ przykład wzorzec gatunkowy XVII-wiecznego powitania przyjmuje według M. Cybulskiego podobnie złożoną strukturę. Składają się na nią inicjujące powitanie, odwitanie oraz (zasadniczo nieobligatoryjne, jednak powszechne) podziękowanie, por.: A: - Pomaga Bóg! B: - Boże wam daj dobry dzień / Boże wam daj szczęście (zdrowie)! A: Dziękuję wam / Boże zapłać! (Cybulski, 1996, 28-32).

11 Jest prawdopodobne, że gwara orawska zachowała relikt dawnego podziękowania za powitanie, w postaci: *Bóg / Boże daj by X. zdrów byl (zdrowa była). Stąd i w modlitwie maryjnej: „Zdrowaś, Mario”, por. Cybulski 2003, 23-29.

12 Podhalańskie powitania przy pracy opracowałem, korzystając z pomnikowego Ilustrowanego leksykonu gwary i kultury podhalańskiej Józefa Kąsia (2015, 359), oraz badań własnych.
} 
łaską, dobrem'; zachowany tu jest metonimiczny związek z czynieniem znaku krzyża w geście chrześcijańskiego błogosławieństwa), por.: Racz Bóg (Pan Jezus) żegnać (pożegnać)! / Niech Pan Bóg (Pan Jezus) przė̇egna (pożegna) - Bóg (Pan Bóg) zapłać! lub prościej: Żegnaj Boże! - Panie Boże żegnaj! (Kurpie). Życzenie to jest nieodzowną częścią komunikacyjnego rytuału obowiązującego w sytuacji, gdy wizyta (spotkanie) zbiega się ze spożywaniem posiłku przez gospodarza. Jest to okoliczność kłopotliwa i krępująca, bowiem otwiera pole pragmatycznego konfliktu: gospodarz jest zobligowany do okazania (przynajmniej werbalnie) gościnności, a jednocześnie sama chęć podzielenia się często ubogim posiłkiem z gościem i zaproszenie do stołu (np.: Pódźcie ku nom, obiaduwaćl śniodaćl wiecerzać!; Prosiemy/ prosemy do nos! itp.) powinna być zinterpretowana jako konwencjonalna deklaracja ${ }^{13}$. Dlatego w rozwijającym się w tym duchu grzecznościowym dialogu jest także miejsce na skuteczne wymawianie się od jedzenia - formułę wyrażającą rozpoznanie intencji mówiącego i grzeczną odmowę, ukrytą w ponowionym życzeniu, np.: Jedzcie (spożywajcie/pożywajcie itp.) z Panem Bogiem (Jezusem)! Można je zresztą dowolnie osłabiać, ujmować w żartobliwy nawias (Jydzcie ta z Panem Jezusym, jo wom ta nie rusym! Podhale). Każdorazowo (także dziś) taka scena oglądana w grzecznościowym teatrze życia codziennego na wsi budzić musi zaciekawienie badacza; dobrze ukazuje jej przebieg relacja Adama Chętnika z Kurpiów (A - gość):
A: Zegnaj Boze!
B: Zegnaj Panie Boze! Prosiemy (np. do śniadania)!
A: Bóg zapłać! Spozywajcie państwo z Bogiem, niech Pan Jezus przezegna! (Chętnik 1936, 33);

co w okolicy Łomży i Wysokiego Mazowieckiego przybiera według Stanisława Dworakowskiego postać:

\section{B: Bóg zapłać! Prosiem do obiadu!}

A: Jedzcie, Państwo, z Bogiem, niech Pan Jezus przeżegna! (Dworakowski 1964, 230).

Dla zrozumienia rangi omawianej formuły w kontaktach społecznych trzeba docenić przyjęty w kulturze ludowej sposób traktowania posiłku jako Bożego daru, owocu wytężonej pracy na świętej roli i związanej z tym sakralizacji także tej, wydawałoby się czysto fizjologicznej, czynności. Nie dziwią więc liczne gesty pobożności, towarzyszące spożywaniu posiłku (dziś zazwyczaj żegnanie się, dawniej - zbiorowa modlitwa), nabożne milczenie i skupienie sięgających po jadło domowników i gości. Nie wyczerpuje to jednak problemu zawartości semantycznej i funkcji takich etykietalnych formuł. Zwrócono mianowicie już dawno uwagę (Udziela 1900, 25; Biegeleisen 1929, 233) na ich funkcję apotropeiczną - zapobiegania możliwemu urokowi, bezwiednie zadanemu jedzącym, przez wygłodniałe spojrzenie ze strony Obcego. W używaniu takich apotropeionów zawiera się więc podwójna logika: wykluczenie obaw gospodarzy (za pomocą przywołanego imienia Boga), że wchodzący ma złe intencje oraz

13 Dlatego bywa że uprzedza się gościa grzecznie: Hybojcie ku nom wiecerzać, ale swój rozum miyjcie! (Podhale) lub Prosiemy, tyzki nie damy! (Kurpie). 
przeciwdziałanie (oddalenie złych skutków) zawczasu niezawinionemu urokowi (dlatego według Seweryna Udzieli przybysz odpowiada na zaproszenie: Jedzcie z Panem Jezusem; Udziela 1900, 25). Ochronnej funkcji imienia Boskiego można zasadnie dopatrywać się także np. w formule życzenia dla kichającego: Dej Boze zdrowie! - Pombóg zapłoc i Duch Świynty! (Orawa)

Systematyczny przegląd etykietalnych formuł religijnych w polskich gwarach wymagałby zgoła osobnego, obszernego opracowania - tak bowiem zasobny i różnorodny pozostaje zgromadzony materiał językowy. Podjęty przeze mnie temat został tu przedstawiony możliwie rzetelnie, jednak daleki jest od wyczerpania. Na pewno rozwinięcia wymaga modlitewna geneza dziesiątków używanych w gwarach formuł i zwrotów grzecznościowych, licznych westchnień i wykrzykników, na co już w niniejszym artykule nie starczyło miejsca. Zachęcający trop wyznaczają tu badania Marii Wojtak nad strukturalnymi i genologicznymi właściwościami ustalonej modlitwy i innych religijnych tekstów, żywo obecnych w oralnej kulturze niepiśmiennej wsi (por. np. Wojtak 2019 i inne ostatnie publikacje tej autorki). Kończąc, wypada rozstrzygnąć istotne pytanie, czy mentalność i światopogląd polskiej wsi pod wpływem ogólnej sekularyzacji kultury i kulturowej interferencji zmienił się tak bardzo, że przedstawiona problematyka nie znajduje oparcia w jej zwyczajach i mentalności. Jeśli prawdą jest stwierdzenie, że wiejskie jest to, czym żyje współczesna wieś, to na pewno w strukturach jej zbiorowej świadomości i mentalności współczesnych potomków polskich chłopów sprawy te odgrywają wciąż istotną rolę, a wieś w znacznym stopniu pozostaje głęboko religijna, co w istocie sprzyja także utrzymywaniu się poczucia odrębności i tożsamości społeczno -kulturowej (Styk 1999, 123-131). Ta traktowana nazbyt krytycznie duchowość niewątpliwie nadal współtworzy bogactwo naszej kultury, wciąż odtwarzane są (por. palmy wielkanocne, wieńce dożynkowe) w kulturze wsi jej symboliczne przekazy i wyobrażenia o sakralnej wartości ziemi i świętości rolniczego trudu, chleba i godności przodków. Pełne takich odniesień są również patriotyczne uroczystości urządzanie z dużym rozmachem przez lokalne władze samorządowe. Dziedzictwo kultury duchowej przodków z wolna przestaje być pojmowane (wśród wiejskich elit) jako wstydliwy bagaż przeszłości. Także pewne elementy wiejskiej etykiety są pod tym względem nadal atrakcyjne i zaskakująco mocno zakorzenione w tradycyjnym systemie wartości. Mogą zatem zostać w jakiejś części podtrzymane. Nie wszystko jest więc oczywiste - odpowiedziałbym potencjalnym oponentom, trawestując wzorem Izabelli Bukraby-Rylskiej (2017), tytuł ważnej książki Czesława Robotyckiego (1998).

\section{Literatura}

Bartmiński J. (2018), Robota i praca: dwa profile pojęcia - dwie formacje kulturowe?, [w:] Praca ludzka w perspektywie interdyscyplinarnej, red. A. Bagłajewski, J. Bartmiński i in., Lublin, s. 273-292.

Biegeleisen H. (1929), Lecznictwo ludu polskiego, Kraków.

Bukraba-Rylska I. (2008), Socjologia wsi polskiej, Warszawa.

Bukraba-Rylska I. (2010), Jak oświecić polskich Irokezów, „Rzeczpospolita” 20.10.2019. 
Bukraba-Rylska I. (2017), Polska wieś w badaniach socjologicznych, czyli nic nie jest oczywiste, [w:] Dynamika rozwoju gwar słowiańskich w XXI wieku, red. D.K. Rembiszewska, Warszawa, s. $245-258$.

Chętnik A. (1936), Pożywienie Kurpiów: jadło i napoje zwykte, obrzędowe i głodowe, Kraków. http://pbc.biaman.pl/dlibra/docmetadata? $\mathrm{id}=32200 \&$ from $=\&$ dirids $=1 \&$ ver_id=\&lp=7\&QI=. 11-21.04.2019.

Chudzik A. (2002), Mowne zachowania magiczne w ujęciu pragmatyczno-kognitywnym, Kraków.

Cross F.L., Livingstone E.A. (2004), Encyklopedia Kościoła, t. 1-2, Warszawa.

Cybulski, M. (1994), Pan i stuga. Niektóre społeczne uwarunkowania zmian w polskich obyczajach językowych, [w:] Uwarunkowania i przyczyny zmian językowych. Zbiór studiów, red. E. Wrocławska, Warszawa, s. 31-39.

Cybulski M, (1996), Polskie formuly powitalne od XVI do połowy XVIII wieku, „Prace Naukowe Uniwersytetu Śląskiego. Prace Językoznawcze”, t. 24. Studia historycznojęzykowe, red. W. Grybosiowa, A. Kowalska, Katowice, s. 27-37.

Cybulski M. (2003), Obyczaje językowe dawnych Polaków. Formuły werbalne $w$ dobie średniopolskiej, Łódź.

Dworakowski S. (1964), Kultura społeczna ludu wiejskiego na Mazowszu nad Narwia, Białystok.

Golachowska E. (2006), Język i kultura mieszkańców wsi włościańskich i szlacheckich dawnej ziemi drohickiej na Podlasiu. Studium socjolingwistyczne, Warszawa

Kałwa D. (2008), Polska doby rozbiorów i międzywojenna, [w:] Obyczaje w Polsce od średniowiecza do czasów współczesnych, red. A. Chwalba, Warszawa, s. 221-336.

Karpeta P., Radziszewska O. (2021), O ludowym pochodzeniu martwicy z To lubię $i$ jej pokrewieństwie z mara pcimska, „Literatura Ludowa” 2021 (w druku)

Kąś J., Sikora K. (1994), Konwencjonalne zwroty grzecznościowe w gwarach (na przykładzie kilku gwar Małopolski południowej), „Etnolingwistyka”, nr 6, s. 83-93.

Kąś J. (1994), Kulturowy stereotyp mężczyzny $i$ kobiety $w$ środowisku wiejskim (na materiale gwar orawskich), [w:] Płeć w języku i kulturze, red. J. Anusiewicz, K. Handke, Wrocław, S. $119-130$.

Kąś J. (2015-2019), Ilustrowany leksykon gwary i kultury podhalańskiej, t. I-XII, różne miejsca wydania, m.in. Bukowina Tatrzańska, Nowy Sącz.

Kowalski P. (2009), Kilka słów o składaniu życzeń, „Colloquia Anthropologica et Communicativa”, t. 1: Tabu, etykieta, dobre obyczaje, s. 177-185.

Kowalski P. (2010a), Gratulanci $i$ winszownicy. Zarys komunikacyjnej historii winszowania, Wrocław.

Kowalski P. (2010b), Zdrowia, szczęścia powinszować. Słowo i magiczna wymiana, „Colloquia Anthropologica et Communicativa”, t. 2: Monety, banknoty i inne środki wymiany, s. 73-95.

KrawczykTyrpa A. (1997), Wolanie do Boga (polskie formuly ludowe), [w:] Frazeologia a religia, red. W. Chlebda, A.M. Lewicki, Problemy Frazeologii Europejskiej, t. II, Warszawa, s. $247-252$.

Leszczyński A. (2020), Ludowa historia Polski. Historia wyzysku i oporu. Mitologia panowania, Warszawa.

Marcjanik M. (1997), Polska grzeczność językowa, Kielce.

Marcjanik M. (2014), Stownik językowego savoir-vivre'u, Warszawa. 
Masłowska E. (2016), Dobre słowo jako tekst magiczny. Życzenie - pozdrowienie - błogostawieństwo, „Język a Kultura”, t. 26, s. 231-243.

Mazurkiewicz M. (1989), Praca $i$ sacrum w polszczyźnie ludowej, „Etnolingwistyka”, $\mathrm{nr} 2$, s. 7-28.

Mazurkiewicz M. (1990), Dwa spojrzenia na pracę. Perspektywa interpretacyjna a znaczenie słowa, [w:] Językowy obraz świata, red. Jerzy Bartmiński, Lublin, s. 129-146.

Mazurkiewicz-Brzozowska M. (1993), Praca. Wybrane warianty znaczenia stowa we wspótczesnej polszczyźnie i ich struktura kognitywna, [w:] Nazwy wartości. Studia leksykalno-semantyczne, t. I, red. J. Bartmiński, M. Mazurkiewicz-Brzozowska, Lublin, s. 133-145.

Nagórko A. (2010), Czy grozi nam zanik poczucia sacrum? Sekularyzacja polszczyzny na tle języków sąsiadów, [w:] Dziedzictwo kulturowe pogranicza, t. III, red. E. Skorupska-Raczyńska, J. Rutkowska, Gorzów Wielkopolski, s. 221-238; także w zasobach internetowych: https:// www.slawistik.hu-berlin.de/de/member/anagorko/poczucie-sacrum. (23.07.2018)

Nagórko A. (2014), Językowa sekularyzacja jako wyzwanie dla leksykografii, [w:] Polonistyka wobec wyzwań współczesności, t. II, red. S. Gajda, I. Jokiel, Opole, s. 391-405.

Nagórko A. (2016), Język ludzi i aniołów... potoczność wobec Sacrum, [w:] Globalizacja a przemiany języków słowiańskich, red. H. Kurek, M. Święcicka, M. Peplińska, Bydgoszcz, s. $277-288$.

Nęcki Z. (2000), Komunikacja międzyludzka, Kraków.

Ożóg K. (1990), Zwroty grzecznościowe wspótczesnej polszczyzny mówionej, „Zeszyty Naukowe Uniwersytetu Jagiellońskiego CMXIII. Prace Językoznawcze”, z. 98, Warszawa-Kraków.

Pawłowicz B. (1896), Kilka rysów z życia ludu w Zalasowej, „Materiały Antropologiczno-Archeologiczne i Etnograficzne Komisji Antropologicznej Akademii Umiejętności w Krakowie”, t. 1, s. 229-265.

Pawłowska A. (2014), Formuly werbalne polskiej etykiety językowej od połowy XVIII do lat sześćdziesiątych XIX wieku. Analiza socjolingwistyczna, Łódź. https://allegro.pl/oferta/ formuly-werbalne-polskiej-etykiety-jezykowej-9986527764.

Pawłowska A. (2016), Wpływ zmian społecznych i światopogladowych na etykietę językowa początków doby nowopolskiej, [w:] Kulturowe uwarunkowania zachowań językowych tradycja i zmiana, Wrocław, s. 107-117.

Pelcowa H. (2015), Wartości w ludowej interpretacji świata, [w:] Tradycja dla współczesności. Ciagłość i zmiana, t. 8: Wartości w języku i kulturze, red. J. Adamowski, M. Wójcicka, Lublin, s. $155-165$.

Pelcowa H. (2018), Sakralizacja pracy i jej wytworów (na przykładzie wypowiedzi mieszkańców wsi), [w:] Praca ludzka w perspektywie interdyscyplinarnej, red. A. Bagłajewski, J. Bartmiński i in., Lublin, s. 309-324.

Piechnik A. (2009), Wizerunek kobiety $i$ mężczyzny w językowym obrazie świata ludności wiejskiej (na przykładzie gminy Zakliczyn nad Dunajcem), Kraków.

Rembiszewska D.K. (red.), (2017), Dynamika rozwoju gwar słowiańskich w XXI wieku, Warszawa, s. 245-258.

Robotycki Cz. (1998), Nie wszystko jest oczywiste, Kraków

Sikora K. (1993), Jak „Pan” zawędrowat na wieś, „Język Polski” LXXII, s. 298-307.

Sikora K. (2011), Winszowanie $i$ dobre słowo w gwarze, „Annales Universitatis Paedagogicae Cracoviensis. Studia Linguistica” VI: Dialog z tradycja, cz. 1., Kraków, s. 171-189. 
Sikora K. (2015), Spelnione sny chtopskiego szczęścia - w tekstach życzeń i oracji kolędniczych, „Annales Universitatis Paedogicae Cracoviensis. Studia Linguistica” VII, Kraków, s. 411-435.

Sikora K. (2020), Życzenie w gwarze i kulturze wsi, Kraków.

Simonides D. (1998), Sacrum jako zasada porządkowania świata w kulturze ludowej, [w:] Człowiek - dzieło - sacrum, red. S. Gajda i H. J. Sobeczko, Opole, s. 95-102.

Simonides D. (2010), Dlaczego drzewa przestały mówić? Ludowa wizja świata, Opole.

Siuciak M. (2000), Zróżnicowanie gatunkowe komunikacji ustnej w XVII wieku, [w:] Gatunki mowy i ich ewolucja, t. 1, red. D. Ostaszewska, Katowice, s. 355-369.

Stomma L. (2002), Antropologia kultury wsi polskiej XIX w. oraz wybrane eseje, Łódź.

Styk J. (1993), Chłopski świat wartości. Studium socjologiczne, Włocławek.

Styk J. (1999), Chłopi i wieś polska w perspektywie socjologicznej i historycznej, Lublin.

Sulima R. (1997), Kultura ludowa i polskie kompleksy, „Regiony”, nr 1, s. 77-81; przedruk: Kultura ludowa i polskie kompleksy, [w:] Czy zmierzch kultury ludowej?, red. A. Dobroński, B. Gołębiowski, S. Zagórski, Łomża, s. 109-115.

Sulima R. (1999), Powitania i rytuaty terytorialności, [w:] $W$ zwierciadle języka i kultury, red. J. Adamowski i S. Niebrzegowska, Lublin, s. 139-151.

Sulima R. (2009), Przemiany polskiego obyczaju (ostatnie dekady), „Colloquia Anthropologica et Communicativa", t. 1: Tabu, etykieta, dobre obyczaje, s. 289-302.

Sulima R. (2014), Społeczne wyobrażenia wsi na przełomie XX i XXI wieku, „Wieś i Rolnictwo”, nr 2 (136), s. 57-63.

Szczepański M.S. (1999), Tożsamość regionalna - w kręgu pojęć podstawowych i metodologii badań. Między tożsamościa indywidualna a społeczna - preliminaria, [w:] Badania nad tożsamościa regionalna, red. A. Matczak, Łódź-Ciechanów, s. 7-17.

Świętek J. (1896), Zwyczaje i pojęcia prawne ludu nadrabskiego, „Materiały AntropologicznoArcheologiczne i Etnograficzne Komisji Antropologicznej Akademii Umiejętności w Krakowie", t. 1, s. 266-362.

Udziela S. (1889), Religia i modlitwa u ludu ropczyckiego, „Wisła”, t. 3, s. 592-603.

Udziela S. (1900), Świat nadzmysłowy ludu krakowskiego, mieszkającego na prawym brzegu Wisty, cz. III, „Wisła”, t. XIV, z. 3, maj-czerwiec 1900, s. 253-273.

Ulanowska S. (1891-1895), Łotysze Inflant Polskich, a w szczególności z gminy wielońskiej powiatu rzeżyckiego. Obraz etnograficzny, cz. I-III, Kraków.

Wiślicz T. (2001), Zarobić na duszne zbawienie, Warszawa.

Wojtak M. (2019), Do boga..., o Bogu..., przed Bogiem... Gatunki przekazu filologicznego $w$ analizie filologicznej, Tarnów.

Wronicz J. (1995), Prace nad Słownikiem gwarowym Śląska Cieszyńskiego, „Język Polski” LXXV, z. 1, s. 53-56. 